\title{
Reaction of selected potato varieties to Clavibacter sepedonicus infestation under changing weather conditions
}

\author{
Grzegorz Gryń (D) Milena Pietraszko • Włodzimierz \\ Przewodowski • Katarzyna Franke • Mirosław \\ Nowakowski • Mateusz Nowakowski
}

Accepted: 4 February 2021 / Published online: 20 February 2021

(C) The Author(s) 2021

\begin{abstract}
The results of the studies carried out over the last 50 years have not provided a clear answer to questions concerning the interaction between Clavibacter sepedonicus (Cs), potato and the environment. The reason is insufficient knowledge of the biology of the causal agent of ring rot, problems of research methodology and the influence of many environmental and biotic factors on the degree of plant infestation. The research conducted in the years 2013-2016 in the Plant Breeding and Acclimatization Institute - National Research Institute concerned the determination of the influence of weather conditions, involved the influence of temperature and Sielianinov hydrothermal coefficient on the development of Cs bacteria in stems and progeny tubers, as well as the occurrence of disease symptoms on plants and in tubers of eight potato varieties. It was found that genotype had the greatest impact on leaf
\end{abstract}

G. Gryń $(\bowtie) \cdot$ K. Franke · M. Nowakowski ·

M. Nowakowski

Division in Bydgoszcz, Plant Breeding and Acclimatization

Institute - National Research Institute, Al. Powstańców Wlkp. 10, 85-090 Bydgoszcz, Poland

e-mail: g.gryn@ihar.edu.pl

M. Pietraszko

Division in Jadwisin, Plant Breeding and Acclimatization Institute - National Research Institute, Szaniawskiego 15, 05-140 Jadwisin, Poland

e-mail: m.pietraszko@ihar.edu.pl

W. Przewodowski

Division in Bonin, Plant Breeding and Acclimatization Institute National Research Institute, 76-009 Bonin, Poland

e-mail: w.przewodowski@ihar.edu.pl and tuber infestation, while weather conditions were less significant. The results of correlation analysis indicate that the weight of tubers of plants infected by Cs increased statistically significantly with increases in air and soil temperature. On the other hand, air and soil temperature in the initial vegetation period did not significantly affect the number of potato plant tubers infested by Cs. In a 4-year experiment, it was not shown how air and soil temperature and the Sielianinov hydrothermal coefficient affected the degree of potato leaf and tuber infestation. In most cases, potato infestation by $\mathrm{Cs}$ caused a decrease in yield.

Keywords Clavibacter sepedonicus, bacterial ring rot of potato, weather conditions

\section{Introduction}

Clavibacter sepedonicus (Cs) is a quarantine organism (Li et al. 2017; Nouioui et al. 2018). It officially exists in 31 countries on three continents. The problem of potato ring rot is constantly being raised as a disease whose economic losses are not directly related to yield losses (De Boer 1987; Kůdela 2007). The financial losses associated with the occurrence of the disease in a given territory are mainly influenced by: a ban on potato cultivation, export restrictions and controlled control measures covering the entire production area. According to van der Wolf et al. (2005), natural factors for the spread of disease such as the presence of weeds in crops, potato rotation with other plants, and the movement of 
bacteria from plant to plant in soil do not play a significant role in the epidemiology of the pest. The survival of Cs bacteria in soil and water is low and the manner in which the bacteria spreads by this route is often neglected (van der Wolf and van Beckhoven 2004; Kakau et al. 2004). However, volunteer plants are a serious problem. Aphids and potato beetles are considered to be a source of the disease's spread, but their importance is minor (Van der Wolf et al. 2005). Much more important factors relating to the severity of the occurrence and spread of the disease are agrotechnical aspects. The use of clean equipment at every stage of production (Nelson 1980; Howard et al. 2015; Stevens et al. 2017), compliance with phytosanitary regulations (EC 1993), the use of healthy, certified seed potatoes play a fundamental role in preventing the disease. While the practice of cutting seed potatoes is common in North America, in Europe the practice of cutting seeds before planting is increasingly rare and unacceptable with the current state of knowledge (Van der Wolf et al. 2005; Nolte et al. 2020). The influence of the weather conditions on the occurrence and intensity of symptoms on leaves and in the tuber yield is constantly being addressed (Logdson 1967; Paquin and Genereux 1976; Bishop and Slack 1987a, b; Westra and Slack 1994; Westra et al. 1994; Hukkanen et al. 2005; Kaemmerer et al. 2007; Hill et al. 2011). So far, the study results have not given a clear answer to questions about the interaction between the pathogen, the plant and the environment. One of the reasons is the limited possibility of studies on the influence of various biotic and abiotic factors on the epidemiology of potato ring rot resulting from the restrictions imposed on the studies on Cs. It is difficult to create a model for predicting the occurrence of symptoms of ring rot on leaves, which would be an additional tool in controlling the disease (Hill et al. 2011). The influence of many environmental factors as well as other data, i.e. differences in susceptibility of potato genotypes to Cs infection and differences in the occurrence of disease symptoms among cultivated varieties (Hill et al. 2011) and the changing virulence of the pathogen are analysed. In recent years, an increase in the frequency of extreme meteorological phenomena has also been evident, i.e. high temperatures in the growing season and droughts preceded by rapid precipitation or rapid temperature changes. The potato's weather requirements means the air and soil temperatures play an essential role in the yield of this plant (Rykaczewska 2015). Potato is a species with a relatively shallow and different root system in individual varieties. The potato's climatic requirements change at different stages of its growth. Potato belongs to the group of plants sensitive to water shortage and excess.

The aim of the study was to determine the influence of weather conditions, mainly the influence of temperature and Sielianinov hydrothermal coefficient, to the recognition of periods of drought and its severity on the development of Cs bacteria in stems and progeny tubers, as well as the occurrence of disease symptoms in the selected potato varieties.

\section{Material and methods}

Plot experiment

The research was conducted in the years 2013-2016 in the Plant Breeding and Acclimatisation Institute - PIB, Branch in Bydgoszcz, Poland. In the experiment six varieties (Courage, Gwiazda, Ikar, Jurek, Oberon, Sagitta) were used in the first year, in the remaining three years - eight varieties (Annabelle, Bosman, Courage, Gwiazda, Ikar, Jurek, Oberon, Sagitta). The cultivars for the tests were selected on the basis of a pilot experiment, taking into account susceptibility to Cs, earliness and usefulness of potatoes. All varieties except two (Bosman, Ikar) are edible. Annabelle and Gwiazda cultivar are registered as early, Courage, Jurek, Oberon, Sagitta are registered as medium-early, Bosman and Ikar as medium-late. The tubers used were free from quarantine diseases, which was confirmed by a document with tests carried out in a certified laboratory. Before planting, seed potatoes were inoculated with a suspension of Cs bacteria. A mucoidal strain NCPPB 4053 with a cell concentration of $2.5 \times 10^{8} \mathrm{cfu} / \mathrm{ml}(0.01 \mathrm{M}$ phosphate buffer, $\mathrm{pH}$ 7.2) was used in the research. In each year, 10 tubers of a given variety were used for the research. In the area of each eye of the tuber, five punctures were made with a scalpel immersed in the bacteria solution each time. An additional five tubers were the negative control, and were punctured using the same PB buffer (0.01 M phosphate buffer, $\mathrm{pH}$ 7.2). Immediately after inoculation, the tubers were planted into the soil at intervals of $40 \mathrm{~cm}$ in the ridge, keeping a distance of $70 \mathrm{~cm}$ between the ridges. The tubers were planted into the lessive soil with a granulometric composition - light clay sand. The soil of the test stand was slightly acidic (pH 6.2-6.5) and had a high content of 
phosphorus, potassium and magnesium. Mineral fertilization was applied before the potato cultivation. Protection against beetles and fungal diseases was also provided during the plant growing season. To examine the effect of precipitation on leaves and tubers infestation, plants were not irrigated. Weeding treatments were carried out manually. During the growing season, the air temperature and the amount of precipitation were constantly measured by means of a meteorological station located in the experimental plots. Soil moisture and temperature were measured twice a week throughout the entire potato growing season. Soil moisture was determined by the weight method. The Sielianinov hydrothermal coefficient was calculated, a measure of precipitation efficiency measured separately in each decade of the month. Depending on the value of the coefficient $(<0.40 ; 0.41-0.70 ; 0.71-1.0 ; 1.01-1.3$; $1.31-1.6 ; 1.61-2.0 ; 2.01-2.50 ; 2.51-3$ and $>3$ ), the decade of the month was characterised as extremely dry, very dry, dry, rather dry, optimal, rather moist, moist, very moist and extremely moist (Skowera and Puła 2004). In the period from the 3 rd decade of June to the 3rd decade of August an intensive tuber formation and tuber yield accumulation take place. This is the period when potato plants have the greatest demand for water. On this basis, each year the average Sielianinov coefficient was provided separately for the period June-July and August-September, except for May, when there is little demand of potatoes for rainwater. The speed of emergence and development of plants in the initial period of growing season is determined mainly by soil temperature. The average values for the periods MayJuly and August-September were used to check the effect of air and soil temperatures on the degree of infection of potato plants by Cs.

\section{Microbiological analysis}

In order to determine the Cs population size in the plant during the growing season, following the flowering period, three leaves were taken from each potato stem, without symptoms of disease or wilting. For the research, petioles were used, cut with a sterile scalpel into $5 \mathrm{~mm}$ long pieces. In this form the samples were prepared for further analysis as described below. The material taken from one potato plant was a sample. During the growing season, the symptoms of ring rot were observed on plants. Tubers were harvested manually in September, separately from each plant. The harvested tuber yields were counted and weighed, then each tuber was cut in half using sterile knives in order to determine whether it was infected with a symptomatic form of disease. Material for microscopic analyses was taken only from tubers without characteristic lesions of disease. The infested tubers were discarded without taking any research material from them. A cone with a base diameter of about $6 \mathrm{~mm}$ was cut from the heel end of the remaining progeny tubers, from a single plant. Pieces of tubers cut from one plant were placed in sterile bacteriological containers and constituted a single sample.

Tubers were stored in a controlled temperature room at $4{ }^{\circ} \mathrm{C}$ (during the winter) for 5 months. They were then cut again, along the cut made earlier and any symptoms of infection were observed.

The quantitative determination of bacterial populations in plant material from leaves and tubers was carried out using the indirect immunofluorescence method (IFAS), in accordance with Council Directive 2006/56/ EC. Plant material from leaves (in July) and tubers (in September) was shaken in sterile plastic bacteriological containers in 10 and $5 \mathrm{ml}$ of maceration buffer $(0.05 \mathrm{M}$ phosphate buffer, $\mathrm{pH} 7.0$ ) for $4 \mathrm{~h}$, respectively. Then the samples were concentrated by centrifugation $\left(10,000 \mathrm{rpm}, 10 \mathrm{~min}, 4{ }^{\circ} \mathrm{C}\right)$ and suspension of the sediment in $1 \mathrm{ml}$ of $0.01 \mathrm{M}$ phosphate buffer at $\mathrm{pH}$ 7.2. In order to facilitate the identification of Cs bacteria, 10-fold (for samples from leaves and tubers) and additionally 100-fold (for samples from tubers) sample dilutions were made. The samples were applied on slides (ThermoScientific, 10 well $6.7 \mathrm{~mm}$ ), dried on a heating plate $\left(37^{\circ} \mathrm{C}\right)$ and then fixed over a flame. Polyclonal antibodies (LoeweBiochemica $\mathrm{GmbH}$ ) and conjugate (LoeweBiochemica $\mathrm{GmbH}$, -Cy3) were used to stain Cs cells. Staining using monoclonal antibody kit (Agdia) was used to confirm the presence of Cs cells in samples in which cross reactions occurred. The observation was carried out at 1000x magnification (Nikon Eclipse Ci) counting typical size $(0.5-1.0 \mu \mathrm{m})$ and shape of bacterial cells in 40 microscope fields of view.

\section{Statistical analysis of the results}

For the evaluation and statistical calculations, the infection scale was used, whose grades corresponded to the average number of Cs cells in the microscope's field of view and the approximate number of Cs cells in leaf and tuber suspension (Table 1). The percentage of tubers infected with a symptomatic form of the disease found 
Table 1 Scale of tuber latent infection by Cs, based on the IF test

\begin{tabular}{llll}
\hline Level of infection & $\begin{array}{l}\text { Number of Cs cells observed in } \\
\text { the microscope field of vision }\end{array}$ & $\begin{array}{l}\text { Mean number of Cs cells in 1 ml of } \\
\text { petiole extract and heel tuber fragments }\end{array}$ & $\begin{array}{l}\text { Number of Cs cells } \\
\text { in the plant }\end{array}$ \\
\hline 1 & $0-20$ in the preperation window & $<1.9 \times 10^{4}$ & low \\
2 & $0-5$ & $2.0 \times 10^{4}-1.9 \times 10^{6}$ & medium \\
3 & $6-10$ & $2.0 \times 10^{6}-6.9 \times 10^{7}$ & high \\
4 & $11-25$ & & \\
5 & $26-75$ & $7.0 \times 10^{7}-4.9 \times 10^{8}$ & \\
6 & $76-150$ & & \\
7 & $151-300$ & $>5.0 \times 10^{8}$ & very high \\
8 & $301-500$ & & \\
\hline
\end{tabular}

after the growing season and the percentage of tubers with symptoms observed in spring, after the storage period, were given. The yield of control plants and Cs inoculated plants was compared with the t-Student's test for independent samples.

An assessment of the impact of the cultivated potato variety and the year of the study (with different climatic conditions) on the size of bacterial populations in stems and progeny tubers (expressed in scale) and on yield was conducted. The impact of the degree of tuber infection on tuber weight and number was assessed.

The Spearman correlation between tuber and leaf infestation, and air and soil temperature in May-July and August-September, and the Sielianinov coefficient in June-July and August-September was performed. All statistical analysis and tests were performed using the Statistica 8 software.

\section{Results}

\section{Weather conditions}

During the period from 2013 to 2016, weather conditions differed significantly. The highest average rainfall was recorded in 2013 and 2014, the lowest in 2015 (Fig. 1.). The distribution of rainfall was found to be more favourable for plant development in 2015 and 2016. The year 2013 was characterised by warm June and August and cool September. In 2014, the average air and soil temperature was low in May and very high in July. The warmest start (May-July) of the potato growing season was recorded in 2016, the coldest in 2015. In the same year, August-September proved to be the warmest period (Tables 2 and 3).

Infection of leaves and tubers by $\mathrm{Cs}$

The reaction of potato varieties to leaf and tuber infection by Cs varied depending on the year of the study. Based on the results obtained, the varieties were divided into two groups. The first group with a degree of tuber infection $<4.5$ and the second group $>4.5$ (Table 4).

In 2013, low leaf and tuber infection (except for Gwiazda and Jurek varieties) was reported compared to other years of the study. In 2014, the greatest diversification of Cs infection of tubers among the tested varieties was observed. Tuber infestation was the highest in the case of Courage, Gwiazda and Jurek varieties, while in Annabelle and Oberon varieties it was the lowest in a four-year experiment (a three-year study for Annabelle). No Cs cells were found in the tubers of the Ikar variety.

The highest (for all tested varieties) leaf infection in the 4-year test cycle was found in 2015. The Bosman, Ikar, Oberon varieties showed very high Cs infection of the aboveground part, while the Gwiazda, Jurek, Sagitta varieties showed high Cs infection. That year, the lowest air and soil temperatures were recorded in the initial growing season (May-July) and no water shortage was found during June-July.

In 2016, the lowest leaf infection within the variety was recorded for Bosman, Courage, Gwiazda, Ikar, and Sagitta. In the remaining varieties, the infection was low except for the Annabelle variety. That year, the most intense rainfall and the highest Sielianinov coefficient in June-July were recorded. That period was also 
Fig. 1 Average precipitation in May-September 2013-2016 measured at the meteorological station located on the experimental plot in Bydgoszcz

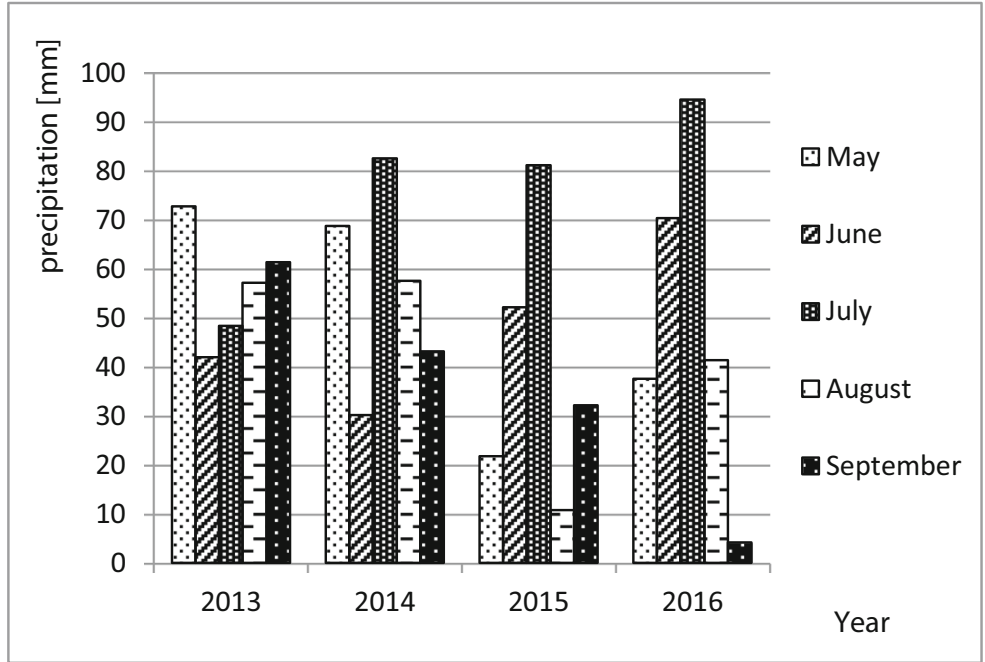

characterised by the highest soil and air temperature in the May-July period. In 2016, very high tuber infection among the Annabelle, Ikar and Sagitta varieties was recorded in a 4-year test cycle and high infection for the Gwiazda variety.

The symptoms in tubers observed after the harvest (autumn) occurred in all varieties except Courage and Ikar. The highest number of tubers with characteristic changes in the conductive tissue was found in 2014 in the Gwiazda (three tubers) and Sagitta (six tubers) varieties. That year, the highest number of varieties whose inoculated plants were of lower height as compared to the control ones (Bosman, Gwiazda, Ikar, Jurek, Sagitta) was also found (Fig. 2). In 2016, no changes were observed in the growth of Cs inoculated and control plants. In group II of varieties, a significant increase in the number of tubers with symptoms found after the storage period was observed.

The results of correlation analysis indicate that the weight of tubers infected with Cs increased statistically significantly with air and soil temperature in the initial (May-July) and final (August-September) vegetation periods (Table 5). On the other hand, air and soil temperature in the initial vegetation period did not significantly affect the number of potato plant tubers infected by Cs. In the assumed experimental layout, the weather conditions did not affect the degree of tuber infection in both groups of varieties. An increase in air and soil temperature in the May-July period caused a decrease in leaf infection in the second group of varieties.

Table 2 Average air and soil temperatures in individual decades in May-September and average temperatures in the first half of the MayJuly growing season and in August-September on the experimental plot in Bydgoszcz

\begin{tabular}{|c|c|c|c|c|c|c|c|c|c|c|c|c|c|c|c|c|c|c|}
\hline \multirow{2}{*}{$\begin{array}{l}\text { Year of } \\
\text { study }\end{array}$} & \multirow{2}{*}{$\begin{array}{l}\text { Mean } \\
\text { temperature } \\
{\left[{ }^{\circ} \mathrm{C}\right]}\end{array}$} & \multicolumn{3}{|l|}{ May } & \multicolumn{3}{|l|}{ June } & \multicolumn{3}{|l|}{ July } & \multicolumn{3}{|c|}{ August } & \multicolumn{3}{|c|}{ September } & \multirow{2}{*}{$\begin{array}{l}\text { May- } \\
\text { July }\end{array}$} & \multirow{2}{*}{$\begin{array}{l}\text { August- } \\
\text { September }\end{array}$} \\
\hline & & I & II & III & I & II & III & I & II & III & I & II & III & I & II & III & & \\
\hline 2013 & Air & 16,1 & 16,8 & 13,8 & 17,3 & 20,6 & 18,3 & 20,2 & 18,1 & 24,5 & 23,2 & 18,5 & 19,5 & 15,5 & 12,6 & 9,8 & 18,4 & 16,5 \\
\hline 2014 & & 11,0 & 13,5 & 17,6 & 18,8 & 16,8 & 15,5 & 22,2 & 21,9 & 25,7 & 20,3 & 17,7 & 17,0 & 16,5 & 17,8 & 12,4 & 18,1 & 17,0 \\
\hline 2015 & & 13,3 & 13,0 & 14,6 & 17,9 & 16,8 & 16,3 & 21,7 & 19,3 & 18,5 & 24,4 & 23,6 & 20,6 & 15,6 & 16,7 & 12,9 & 16,8 & 19,0 \\
\hline 2016 & & 15,1 & 13,2 & 20,4 & 18,7 & 17,7 & 21,9 & 18,7 & 19,0 & 21,7 & 18,2 & 17,2 & 19,8 & 18,9 & 17,7 & 13,7 & 18,5 & 17,6 \\
\hline 2013 & Soil & 15,2 & 17,2 & 15,8 & 18,3 & 22,4 & 21,2 & 21,7 & 22,7 & 26,2 & 26,2 & 22,6 & 19,5 & 18 & 14,7 & 11,8 & 20,1 & 18,8 \\
\hline 2014 & & 12,5 & 14,1 & 18,4 & 19,4 & 20,9 & 17,5 & 22,2 & 24,2 & 24,7 & 24,5 & 20,1 & 17,2 & 17,6 & 18 & 13,9 & 19,3 & 18,6 \\
\hline 2015 & & 14,1 & 15,3 & 17,7 & 20,7 & 20,2 & 18 & 23,9 & 21 & 21,4 & 24,9 & 26,3 & 22,4 & 17,6 & 17,5 & 15,1 & 19,1 & 20,6 \\
\hline 2016 & & 15,8 & 15,7 & 21,5 & 22,7 & 20,5 & 23,1 & 21,2 & 20,1 & 22,8 & 19,6 & 19,3 & 20,8 & 20,5 & 20,4 & 16,1 & 20,4 & 19,5 \\
\hline
\end{tabular}


Table 3 Average values of Sielianinov hydrothermal coefficient in particular decades in May-September and the average value for JuneJuly and August-September

\begin{tabular}{|c|c|c|c|c|c|c|c|c|c|c|c|c|c|c|c|c|c|}
\hline \multirow[t]{2}{*}{ Year of study } & \multicolumn{3}{|l|}{ May } & \multicolumn{3}{|l|}{ June } & \multicolumn{3}{|l|}{ July } & \multicolumn{3}{|c|}{ August } & \multicolumn{3}{|c|}{ September } & \multirow{2}{*}{$\begin{array}{l}\text { June-- } \\
\text { July }\end{array}$} & \multirow{2}{*}{$\begin{array}{l}\text { August-- } \\
\text { September }\end{array}$} \\
\hline & I & II & III & I & II & III & I & II & III & I & II & III & I & II & III & & \\
\hline 2013 & 0,91 & 0,68 & 3,39 & 0,53 & 0 & 1,79 & 0,95 & 0,74 & 0,64 & 1,04 & 1,66 & 0,11 & 1,01 & 2,35 & 1,65 & 0,78 & 1,30 \\
\hline 2014 & 1,44 & 1,35 & 1,98 & 0,41 & 0,67 & 0,72 & 3,21 & 0,22 & 0,26 & 1,01 & 1,15 & 0,98 & 1,36 & 0,02 & 1,65 & 0,91 & 1,03 \\
\hline 2015 & 0,69 & 0,85 & 0,11 & 0,2 & 1,5 & 1,44 & 0,34 & 2,57 & 1,31 & 0,09 & 0,13 & 0,27 & 1,62 & 0,41 & 0,02 & 1,23 & 0,42 \\
\hline 2016 & 0,79 & 0,7 & 0,8 & 0,09 & 2,77 & 0,9 & 1,1 & 2,69 & 1,05 & 1,45 & 0,2 & 0,59 & 0,21 & 0,01 & 0 & 1,43 & 0,41 \\
\hline
\end{tabular}

Yield decrease

The average number of tubers harvested in 2013 and 2014 from single control plants was 8.9 and 8.1 respectively, while inoculated plants formed slightly more tubers (Table 6). In 2015 and 2016 the reverse trend was observed, i.e. more tubers were found in the control variant. The highest average weight of control tubers was recorded in 2015 and 2016 amounting to $661 \mathrm{~g}$ and $921.4 \mathrm{~g}$, respectively. In both of these potato growing seasons, there were statistically significant differences in yield of inoculated plants (435.2 $\mathrm{g}$ in 2015 and $681.6 \mathrm{~g}$ in 2016) as compared to control plants.

On the basis of the analysis of variance, it was found that genotype had the greatest influence on leaf and tuber infection in the first group of cultivated potato varieties (Table 7). In the case of the second group of potato varieties, weather conditions had the greatest effect on leaf infection. In both groups of potato varieties, the growing season had a significant impact on the yield (weight and number) of tubers. In addition, it was shown that the interaction between the cultivated variety and weather conditions in a given year significantly influenced the differences in leaf infection and tuber weight in both groups of potato varieties. Only in the second group of varieties, there was a significant impact of the degree of leaf infection on tuber yield.

\section{Discussion}

Effect of weather condition and genotype on symptoms of ring rot

The occurrence of symptoms of Cs infection on potato leaves and in potato tubers is dependent on many pathogen-plant interactions. The size of the pathogen population in the plant causing the infection and the occurrence of symptoms varies significantly between potato varieties (Bishop and Slack 1987a, De Boer and McCann 1990, Westra and Slack 1994, Kawchuk et al. 1998, Pietraszko et al. 2018, Pánková et al. 2007, Pánková et al. 2019, Whitworth et al. 2019). Hill et al. 2011 believe that the degree of infection and the rate of Cs population development in the plant are more influenced by the habitat conditions such as temperature and humidity rather than varietal characteristics. According to these authors, the disease symptoms of varieties considered to be resistant and susceptible showed a similar response to changes in environmental conditions. The expression of symptoms on leaves remained stable in the varieties studied by Hill et al. 2011 during 15-year study period. Earlier studies (Logdson 1967; Manzer et al. 1987) also confirm that the environment is crucial for the expression of symptoms of ring rot. In authors' own research, the symptoms of ring rot during the growing season in the form of differences in the growth of inoculated and control plants and leaf wilting and chlorosis were observed in the Bosman, Gwiazda, Jurek and Sagitta varieties. The symptoms in tubers occurred with different intensity depending on the variety. No changes in the conductive tissue of tubers cut in half by sterile knives were recorded in the Courage and Ikar varieties. The influence of temperature and humidity during potato growing season on the occurrence of symptoms of ring rot in the plant was studied by Paquin and Genereux (1976). The authors observed that varieties resistant to ring rot were more infected in the northern regions of Quebec (Canada), where the number of degree-days and average air temperature were lower but the photoperiod was longer than that in the southern part of the province. Manzer et al. (1987), on the other hand, found that high temperatures and lack of rainfall accelerate the development of symptoms, while 
Table 4 The response of potato varieties to Cs infection expressed in the degrees of leaf and tuber infestation, the occurrence of differences in the plant growth compared to the control plants and symptoms on the plants and in the tubers after harvesting and after storage

\begin{tabular}{|c|c|c|c|c|c|c|c|c|c|}
\hline \multicolumn{2}{|c|}{ Potato varieties } & \multirow[t]{2}{*}{ Earliness } & \multirow{2}{*}{$\begin{array}{l}\text { Water } \\
\text { requirements }\end{array}$} & \multirow{2}{*}{$\begin{array}{l}\text { Year } \\
\text { of } \\
\text { study }\end{array}$} & \multirow{2}{*}{$\begin{array}{l}\text { Degree of } \\
\text { infection of } \\
\text { leaves }\end{array}$} & \multirow{2}{*}{$\begin{array}{l}\text { Differences in growth } \\
\text { and symptoms on leaves }\end{array}$} & \multirow{2}{*}{$\begin{array}{l}\text { Degree of } \\
\text { infection of } \\
\text { tubers }\end{array}$} & \multicolumn{2}{|c|}{ Symptoms \% } \\
\hline & & & & & & & & $\begin{array}{l}\text { After } \\
\text { harvesting }\end{array}$ & $\begin{array}{l}\text { After } \\
\text { storage }\end{array}$ \\
\hline \multirow{19}{*}{$\begin{array}{l}\text { Group } \\
\text { I }\end{array}$} & \multirow[t]{4}{*}{ Annabelle } & \multirow[t]{4}{*}{ Early } & \multirow{4}{*}{$\begin{array}{l}\text { Medium to } \\
\text { high }\end{array}$} & 2014 & 1 & No & 0,3 & 0 & 0 \\
\hline & & & & 2015 & 1,5 & No & 1,6 & 0,63 & 0 \\
\hline & & & & 2016 & 2,3 & No & 1,7 & 0 & 0 \\
\hline & & & & Mean & 1,6 & - & 1,2 & - & - \\
\hline & \multirow[t]{5}{*}{ Courage } & \multirow[t]{5}{*}{ Medium-early } & \multirow[t]{5}{*}{ Tolerant } & 2013 & 0,5 & No & 1,4 & 0 & 0 \\
\hline & & & & 2014 & 1,12 & No & 2,3 & 0 & 0 \\
\hline & & & & 2015 & 0,8 & No & 0,3 & 0 & 0 \\
\hline & & & & 2016 & 0,5 & No & 1,4 & 0 & 0 \\
\hline & & & & Mean & 0,73 & - & 1,35 & - & - \\
\hline & \multirow[t]{5}{*}{ Ikar } & \multirow[t]{5}{*}{ Medium-late } & \multirow[t]{5}{*}{ Medium } & 2013 & 2,5 & No & 1,2 & 0 & 0 \\
\hline & & & & 2014 & 3,7 & No & 0 & 0 & 0 \\
\hline & & & & 2015 & 4,6 & No & 1,5 & 0 & 0 \\
\hline & & & & 2016 & 1 & No & 2 & 0 & 0 \\
\hline & & & & Mean & 2,95 & - & 1175 & - & - \\
\hline & \multirow[t]{5}{*}{ Oberon } & \multirow[t]{5}{*}{ Medium-early } & \multirow[t]{5}{*}{ Medium } & 2013 & 1 & No & 3,2 & 0 & 2,25 \\
\hline & & & & 2014 & 1,4 & No & 2,3 & 0 & 0 \\
\hline & & & & 2015 & 2,9 & No & 4,1 & 0 & 0 \\
\hline & & & & 2016 & 1,4 & No & 3,2 & 0,83 & 0 \\
\hline & & & & Mean & 1,675 & - & 3,2 & - & - \\
\hline \multirow{19}{*}{$\begin{array}{l}\text { Group } \\
\text { II }\end{array}$} & Bosman & Medium-late & No data & 2014 & 6 & Yes & 6,7 & 0 & 2,65 \\
\hline & & & & 2015 & 8,9 & Yes & 7,6 & 0 & 10,24 \\
\hline & & & & 2016 & 4,3 & No & 6,1 & 2,11 & 4,3 \\
\hline & & & & Mean & 6,4 & - & 6,8 & - & - \\
\hline & Gwiazda & Early & tolerant & 2013 & 4 & Yes & 5,2 & 1,45 & 7,35 \\
\hline & & & & 2014 & 3,1 & Yes & 8,1 & 3,23 & 1,11 \\
\hline & & & & 2015 & 3,8 & Yes & 5,4 & 1,22 & 2,47 \\
\hline & & & & 2016 & 1,6 & No & 6,1 & 0 & 1 \\
\hline & & & & Mean & 3,125 & - & 6,2 & - & - \\
\hline & Jurek & Medium-early & Medium & 2013 & 2,3 & No & 4,8 & 1,01 & 3,06 \\
\hline & & & & 2014 & 0,5 & Yes & 6,9 & 0 & 6,06 \\
\hline & & & & 2015 & 1,4 & Yes & 4,2 & 0 & 1,87 \\
\hline & & & & 2016 & 1,2 & Yes & 4,5 & 0 & 1,5 \\
\hline & & & & Mean & 1,35 & - & 5,1 & - & - \\
\hline & Sagitta & Medium-early & Medium to & 2013 & 1,9 & Yes & 5,8 & 0 & 5,41 \\
\hline & & & high & 2014 & 4,12 & Yes & 5,4 & 5,45 & 0,96 \\
\hline & & & & 2015 & 2,1 & No & 4,9 & 0,91 & 1,83 \\
\hline & & & & 2016 & 1,8 & No & 6,5 & 0 & 2,11 \\
\hline & & & & Mean & 2,48 & - & 5,65 & - & - \\
\hline Mean $\mathrm{fc}$ & r years & & & 2013 & 2 & - & 3,6 & 0,33 & 2,32 \\
\hline & & & & 2014 & 2,6 & - & 4 & 1,15 & 1,42 \\
\hline & & & & 2015 & 3,3 & - & 3,7 & 0,32 & 2,01 \\
\hline & & & & 2016 & 1,8 & - & 3,9 & 0,34 & 1,03 \\
\hline
\end{tabular}


Fig. 2 a Changes in the growth of infected with Cs plants and wilting symptoms in the Gwiazda variety. b Chlorosis between the vascular tissues and curling of leaf blades in the Sagitta variety

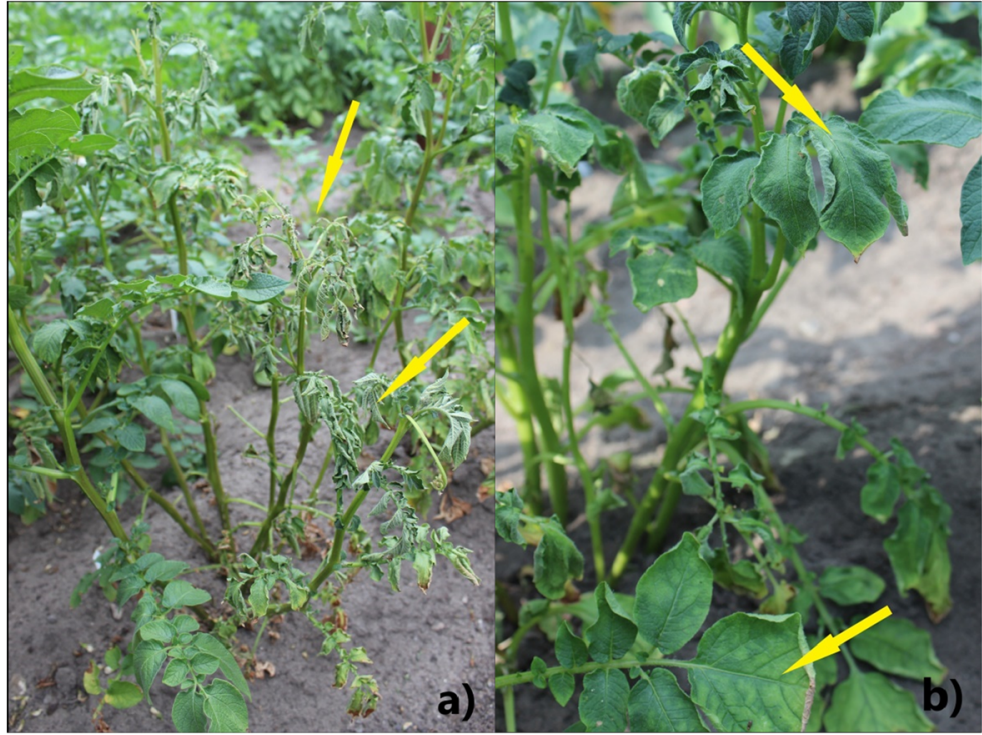

normal and cold conditions delay the appearance of disease symptoms. Also Bishop and Slack (1982) confirmed that the cultivation of potatoes at a constant temperature of $24{ }^{\circ} \mathrm{C}$ caused the number of leaves with symptoms of ring rot to be significantly higher than the cultivation of the same variety at different daily temperatures $\left(12 \mathrm{~h}\right.$ at over $24{ }^{\circ} \mathrm{C}$ and $12 \mathrm{~h}$ at $\left.5{ }^{\circ} \mathrm{C}\right)$.

Effect of weather condition and genotype on leaves and tubers infection

Correlations of the influence of climatic factors on the development of Cs bacteria in the plant were undertaken by Kaemmerer et al. (2007). In the years 2002-2004, the researchers carried out field studies, during which they found significantly higher tuber and stem base infection in the mid-early Agria variety in the year with very high temperature and low humidity. A higher statistically significant infection of the apex and stem base also occurred in the late Sibu variety in the year with moderate weather conditions typical for Germany. Kaemmerer et al. (2007) observed the symptoms of disease only in the Sibu variety in 2004, with a cold first half of the growing season and average rainfall compared to the rest of the study years, and not in 2003, which, according to earlier reports, had climatic conditions suitable for the occurrence of symptoms. In our own research in the first group of varieties (with a

Table 5 The correlation coefficients between environmental parameters and Cs tuber and leaf infection and the weight and number of tubers

\begin{tabular}{|c|c|c|c|c|c|c|c|c|}
\hline \multirow[t]{2}{*}{ Environmental parameters } & \multicolumn{4}{|c|}{ I group of varieties } & \multicolumn{4}{|c|}{ II group of varieties } \\
\hline & $\begin{array}{l}\text { Infection of } \\
\text { tubers }\end{array}$ & $\begin{array}{l}\text { Infection of } \\
\text { leaves }\end{array}$ & $\begin{array}{l}\text { Weight of } \\
\text { tubers }\end{array}$ & $\begin{array}{l}\text { Numer of } \\
\text { tubers }\end{array}$ & $\begin{array}{l}\text { Infection of } \\
\text { tubers }\end{array}$ & $\begin{array}{l}\text { Infection of } \\
\text { leaves }\end{array}$ & $\begin{array}{l}\text { Weight of } \\
\text { tubers }\end{array}$ & $\begin{array}{l}\text { Numer of } \\
\text { tubers }\end{array}$ \\
\hline Air temperature May-July & ns & $\mathrm{ns}$ & 0,27 & $\mathrm{~ns}$ & ns & $-0,22$ & 0,26 & ns \\
\hline Air temperature August-September & ns & - & 0,2 & - & ns & - & 0,31 & - \\
\hline Soil temperature May-July & ns & ns & 0,27 & ns & ns & $-0,22$ & 0,26 & ns \\
\hline $\begin{array}{l}\text { Soil temperature } \\
\text { August-September }\end{array}$ & ns & - & 0,29 & - & ns & - & 0,26 & - \\
\hline $\begin{array}{l}\text { Sielianinov hydrothermal } \\
\text { coefficient June-July }\end{array}$ & ns & ns & 0,36 & 0,16 & ns & ns & 0,52 & 0,23 \\
\hline $\begin{array}{l}\text { Sielianinov hydrothermal } \\
\text { coefficient August-September }\end{array}$ & ns & - & $-0,36$ & - & ns & - & $-0,52$ & - \\
\hline
\end{tabular}

ns- not significant 
Table 6 Weight and number of tubers

\begin{tabular}{|c|c|c|c|c|c|c|c|c|c|}
\hline \multicolumn{2}{|c|}{ Potato varieties } & \multirow[t]{2}{*}{ Year of study } & \multicolumn{4}{|c|}{ Mean tuber's weight from one plant } & \multicolumn{3}{|c|}{ Mean numer of tubers } \\
\hline & & & Cs free $[\mathrm{g}]$ & Cs $[\mathrm{g}]$ & t-test $^{1}$ & $\mathrm{Cs} / \mathrm{Cs}$ free ratio $(\%)$ & Cs free & $\mathrm{Cs}$ & t-test \\
\hline \multirow{15}{*}{ Group I } & Annabelle & 2014 & 210 & 217 & ns & 103,3 & 6,6 & 8,6 & ns \\
\hline & & 2015 & 306 & 275 & ns & 89,9 & 16,4 & 15,9 & ns \\
\hline & & 2016 & 879 & 494 & $* *$ & 56,2 & 14,8 & 12 & ns \\
\hline & Courage & 2013 & 422 & 405 & ns & 96,0 & 9,2 & 8,9 & ns \\
\hline & & 2014 & 382 & 459 & ns & 120,1 & 7,6 & 10,6 & ns \\
\hline & & 2015 & 552 & 476 & ns & 86,2 & 8,2 & 8,5 & ns \\
\hline & & 2016 & 578 & 527 & ns & 91,2 & 6,8 & 8 & ns \\
\hline & Ikar & 2013 & 460 & 479 & ns & 104,2 & 16,2 & 16,1 & ns \\
\hline & & 2014 & 364 & 157 & $* *$ & 43,1 & 10 & 9,4 & $\mathrm{~ns}$ \\
\hline & & 2015 & 468 & 405 & ns & 86,5 & 12,4 & 13,8 & ns \\
\hline & & 2016 & 810 & 437 & $*$ & 53,9 & 19 & 12,9 & $*$ \\
\hline & Oberon & 2013 & 306 & 296 & ns & 96,7 & 7,4 & 8,9 & ns \\
\hline & & 2014 & 440 & 355 & ns & 80,7 & 7,4 & 8,7 & $\mathrm{~ns}$ \\
\hline & & 2015 & 538 & 437 & ns & 81,2 & 16 & 14,1 & ns \\
\hline & & 2016 & 993 & 881 & ns & 88,7 & 13 & 12,1 & ns \\
\hline \multirow[t]{15}{*}{ Group II } & Bosman & 2014 & 616 & 363 & $* *$ & 58,9 & 8,4 & 11,3 & $\mathrm{~ns}$ \\
\hline & & 2015 & 668 & 357 & $* *$ & 53,4 & 8,8 & 12,7 & $* *$ \\
\hline & & 2016 & 720 & 492 & ns & 68,3 & 7,6 & 9,5 & ns \\
\hline & Gwiazda & 2013 & 226 & 285 & ns & 115,7 & 7,6 & 6,9 & ns \\
\hline & & 2014 & 612 & 457 & ns & 74,7 & 8,6 & 9,3 & ns \\
\hline & & 2015 & 562 & 415 & ns & 73,8 & 8,2 & 8,2 & ns \\
\hline & & 2016 & 931 & 616 & $*$ & 66,1 & 11,8 & 10 & ns \\
\hline & Jurek & 2013 & 323 & 380 & ns & 117,8 & 6,8 & 9,9 & ns \\
\hline & & 2014 & 584 & 443 & ns & 75,8 & 8,2 & 9,9 & ns \\
\hline & & 2015 & 1306 & 603 & $* *$ & 46,2 & 15 & 10,7 & $\mathrm{~ns}$ \\
\hline & & 2016 & 1520 & 1245 & ns & 81,9 & 14,2 & 13,3 & $\mathrm{~ns}$ \\
\hline & Sagitta & 2013 & 518 & 402 & ns & 77,7 & 6 & 7,4 & ns \\
\hline & & 2014 & 488 & 337 & ns & 69,0 & 7,8 & 11 & ns \\
\hline & & 2015 & 888 & 514 & $*$ & 57,9 & 13,2 & 11 & $\mathrm{~ns}$ \\
\hline & & 2016 & 937 & 759 & ns & 80,9 & 6,4 & 9,5 & $\mathrm{~ns}$ \\
\hline \multirow{4}{*}{\multicolumn{2}{|c|}{ Mean }} & 2013 & $c^{2} 376$ & $b^{2} 375$ & ns & 99,7 & $\mathrm{bc}^{2} 8,9$ & $b^{2} 9,7$ & ns \\
\hline & & 2014 & c 462 & b 348 & $* *$ & 75,4 & c 8,1 & b 9,9 & $*$ \\
\hline & & 2015 & b 661 & b 435 & $* *$ & 65,8 & a 12,3 & a 11,9 & ns \\
\hline & & 2016 & a 921 & a 682 & $* *$ & 73,9 & ab 11,7 & $a b 10,9$ & $\mathrm{~ns}$ \\
\hline
\end{tabular}

*statistically significant at $P<0,05, * *$ statistically significant at $\mathrm{P}<0,01$, ns- not significant

${ }^{1}$ Student's t test, ${ }^{2}$ values with different letters are statistically different at $P<0.05$

lower number of bacteria in tubers) the influence of varietal characteristics on the degree of leaf and tuber infection was higher than the weather conditions. In the second group of varieties (with a higher degree of tuber infection), the year of the study and the variety had a significant impact only on leaf infection. Similarly to Kaemmerer et al. (2007), the authors did not succeed in correlating the occurrence of symptoms and levels of leaf and tuber infestation with the weather conditions on the basis of the experiments carried out during the 4- 
Table 7 Influence of experimental factors on leaf infection, tuber infection, tuber weight and tuber number - results of variance analysis

\begin{tabular}{|c|c|c|c|c|c|c|c|c|c|}
\hline \multicolumn{2}{|c|}{ Experimental factors } & \multicolumn{2}{|c|}{ Infection of leaves } & \multicolumn{2}{|c|}{ Infection of tubers } & \multicolumn{2}{|c|}{ Weigth of tubers } & \multicolumn{2}{|c|}{ Number of tubers } \\
\hline & & $\mathrm{F}$ value & $p$ value & $\mathrm{F}$ value & $\mathrm{p}$ value & $\mathrm{F}$ value & $\mathrm{p}$ value & $\mathrm{F}$ value & $\mathrm{p}$ value \\
\hline \multirow[t]{5}{*}{ Group I } & Variety & 12,37 & 0,000 & 9,44 & 0,000 & 6,39 & 0,002 & 11,35 & 0,000 \\
\hline & Year of study & 3,40 & 0,036 & 1,48 & 0,231 & 32,50 & 0,000 & 9,73 & 0,000 \\
\hline & Variety x year of study & 2,25 & 0,027 & 1,27 & 0,262 & 6,89 & 0,000 & 3,95 & 0,000 \\
\hline & Degree of infection of tubers & - & - & - & - & 1,10 & 0,366 & 0,77 & 0,645 \\
\hline & Degree of infection of leaves & - & - & - & - & 1,75 & 0,082 & 0,614 & 0,783 \\
\hline \multirow[t]{5}{*}{ Group II } & Variety & 7,07 & 0,001 & 1,35 & 0,262 & 14,92 & 0,000 & 4,96 & 0,008 \\
\hline & Year of study & 7,77 & 0,000 & 1,93 & 0,149 & 44,46 & 0,000 & 0,07 & 0,930 \\
\hline & Variety x year of study & 3,22 & 0,002 & 1,50 & 0,333 & 6436 & 0,000 & 1,74 & 0,096 \\
\hline & Degree of infection of tubers & - & - & - & - & 1065 & 0,392 & 1694 & 0,096 \\
\hline & Degree of infection of leaves & - & - & - & - & 2596 & 0,008 & 1880 & 0,058 \\
\hline
\end{tabular}

year study cycle.. Hukkanen et al. (2005) found that a higher number of Cs 4053 bacteria in tubers of the susceptible variety Hansa and the resistant variety Desiree grown in Finland occurred in 2001, which was characterised by warm July and high rainfall in September. Low temperatures throughout the growing season and high rainfall in July 2000 resulted in a lower number of bacteria in tubers. The authors made different observations in the samples taken from potatoes grown in Denmark. In 2001, characterised by high temperatures during the growing season and high rainfall in August and September, the authors found a lower bacterial population in tubers than in 2000 with moderate temperatures and low rainfall. The results obtained in our own research in 2015 are consistent with the observations of Hukkanen et al. (2005). That year, the lowest air and soil temperatures were recorded in May-July and small amounts of rainfall at the turn of May-June were recorded, and yet bacterial population in leaves in most varieties was high.

According to Hill et al. (2011), the most important factor influencing the severity of the expression of bacterial symptoms is the temperature in the second half of August and the total amount of rainfall in the second half of June. The increased occurrence of the symptoms is explained by the authors by the fact that bacteria which are multiplied in high temperature in vascular bundles with insufficient rainfall in the late stage of potato growing season reduce the availability of water in tissues, resulting in the occurrence of wilting and chlorosis (Marques et al. 2003; Bae et al. 2014). The high amount of rainfall in July and August and the very high average daily temperature in July in 2014 explain the occurrence of differences in the growth of infested and control plants and the increased proportion of tubers with symptoms in the Gwiazda and Sagitta varieties.

Soil temperature and humidity

Soil temperature and humidity also play an important role in the development of infection. According to Logdson (1967), a soil temperature of $25^{\circ} \mathrm{C}$ is optimal for the development of infection. A similar view is held by Dykstra (1942), who stated that at higher soil temperatures and irrigation, the development of symptoms of ring rot is faster, most likely as a result of increased bacterial activity. In the study of Hill et al. (2011), rainfall, especially in the early stages of the growth season, influenced the development of the disease. High soil moisture ensures the maintenance of turgidity and enables the propagation and spread of bacteria in the plant. On the other hand, high moisture in the soil slows down the ripening processes of potatoes and at the same time masks the symptoms of disease. In our own research, very high tuber infection in the Annabelle, Ikar and Sagitta varieties and high infection in the Gwiazda variety in 2016 can be explained by high soil and air temperatures in May-July and intensive rainfall in June-July.

Yield decrease

The yield decrease as a result of potato infestation by Cs has been described differently by researchers. De Boer 
(1987) claimed that the yield decrease as a result of ring rot is small and concerns mainly consumer potatoes. The economic losses result mainly from intolerance of the disease and the associated restrictions on trade. However, the authors emphasised that losses at a single producer may be large, but such cases are rare. Van der Wolf et al. (2005) took a similar view. The authors emphasised that losses caused by the presence of Cs were mainly due to the introduction of control measures on the farm and the loss of sales markets. Hukkanen et al. (2005) observed a yield decrease of $41-56 \%$ in the Hansa variety grown in Finland, while in the more tolerant Desiree variety, the authors did not record a significant yield decrease despite the high number of bacteria in stems and tubers. Hukkanen et al. (2005), like Sletten (1985), observed a yield decrease which resulted from a smaller number of tubers rather than from a smaller weight of individual tubers. Even in 1979 Easton (1979) stated that bacterial infestation would lead to a reduction in yield by $50 \%$ or more. Kůdela (2007), on the other hand, claimed that the yield decrease by more than $50 \%$ is unprecedented in practice. In our own research, there was a decrease in yield in most cases. The average annual yield ratio of inoculated plants to healthy plants for all varieties ranged from 65.8 to $99.7 \%$. The biggest decrease of more than $50 \%$ was recorded in 2014 in the Ikar variety and in 2015 in the Jurek variety. Contrary to the observations of Sletten (1985) and Hukkanen et al. (2005) in the own research, the yield decrease resulted from the lower weight of individual tubers and not from a reduction in the number of tubers from a single potato bush. However, the weight of infected tubers increased with the increase in air and soil temperature in the first and second half of the potato vegetation period and with the Sielianinow hydrothermal coefficient in June-July. Information on the influence of weather conditions on the development of Cs populations in the plant is very important for the epidemiology of the disease. A potato variety had the highest impact on bacterial population in leaves and tubers. Genotype is also the main cause of differences in symptom expression. Differences found in Cs infestation of leaves and tubers of the same varieties in different years are the result of weather conditions. Individual assessment of the effect of one factor on the plant infestation is almost impossible. Increasing the knowledge in this direction requires many years of observation. Rapid weather changes observed over recent years further justify the need to continue research on the behaviour of the Cs population in the plant and the occurrence of symptoms on plants. However potato producers, especially seed potatoes, should systematically observe plantations. The plant flowering period and the time immediately afterwards is the best for observation. It should be remembered that the symptoms on leaves usually appear late in the development stage and are often confused with symptoms of other diseases, drought or natural aging of plants. The observation should not be made immediately after rainfall or after irrigation because the symptoms of wilting may not be noticeable. During field inspections, attention should be paid to the plants with stunted growth, with signs of chlorosis between the vascular tissues and displaying curling of leaf blades. The knowledge of the susceptibility of the cultivar to Cs infection and its reaction to extreme weather conditions (drought, high temperatures) is also highly significant for potato producers. Since the disease generally occurs in the latent form, laboratory examination of tubers is required. The control of the cut tubers after the storage period are also recommended.

Funding This research was financially supported by a grant from the Ministry of Agriculture and Rural Development, Poland.

\section{Declarations}

Ethical approval This article does not contain any studies with human participants or animals performed by any of the authors.

Conflict of interest The authors declare that they have no conflict of interest, the study described is original, has not been published previously. All authors consent to this submission. All authors have contributions on everypart of the study.

Open Access This article is licensed under a Creative Commons Attribution 4.0 International License, which permits use, sharing, adaptation, distribution and reproduction in any medium or format, as long as you give appropriate credit to the original author(s) and the source, provide a link to the Creative Commons licence, and indicate if changes were made. The images or other third party material in this article are included in the article's Creative Commons licence, unless indicated otherwise in a credit line to the material. If material is not included in the article's Creative Commons licence and your intended use is not permitted by statutory regulation or exceeds the permitted use, you will need to obtain permission directly from the copyright holder. To view a copy of this licence, visit http://creativecommons.org/licenses/by/4.0/. 


\section{References}

Bae, Y. M., Zheng, L., Hyun, J. E., Jung, K. S., Heu, S., \& Lee, S. Y. (2014). Growth characteristics and biofilm formation of various spoilage bacteria isolated from fresh produce. Journal of Food Science, 79(10), M2072-M2080. https://doi.org/10.1111/1750-3841.12644.

Bishop, A. L, \& Slack, S. A. (1982). Effect of temperature on development of ring rot in potato. Phytopathology, 72, 1382.

Bishop, A. L., \& Slack, S. A. (1987a). Effect of inoculum dose and strain of Clavibacter michiganensis subsp. sepedonicus on symptom development in potatoes. Phytopathology, 77, $1085-1089$.

Bishop, A. L., \& Slack, S. A. (1987b). Effect of cultivar inoculums dose and preparation strain variation and plant growth conditions on the eggplant assay for bacterial ring rot. American Potato Journal, 64, 227-234.

De Boer, S. H. (1987). The relationship between bacterial ring rot and North American seed potato export market. American Potato Journal, 64, 683-694.

De Boer, S. H., \& McCann, M. (1990). Detection of Corynebacterium sepedonicum in potato cultivars with different propensities to express ring rot symptoms. American Potato Journal, 67, 685-694.

Dykstra, T. P. (1942). Compilation of results in control of potato ring rot on 1941. American Journal of Potato Research, 19, 175-196.

Easton, G. D. (1979). The biology and epidemiology of potato ring rot. American Potato Journal, 56, 459-460.

EC. (1993). Council directive 93/85/EC. Official Journal of the European Communities, L-259, 1-24.

Hill, B. D., Kalischuk, M., Waterer, R. W., Bizimungu, B., Howard, R., \& Kawchuk, L. M. (2011). An environmental model predicting bacterial ring rot symptom expression. American Journal of Potato Research, 88, 294-301. https://doi.org/10.1007/s12230-011-9193-4.

Howard, R. J., Harding, M. W., Daniels, G. C., Mobbs, S. L., Lisowski, S. L. I., \& De Boer, S. H. (2015). Efficacy of agricultural disinfectants on biofilms of the bacterial ring rot pathogen, Clavibacter michiganensis subsp. sepedonicus. Canadian Journal of Plant Pathology, 37, 273-284.

Hukkanen, A., Karjalainen, R., Nielsen, J., \& Van der Wolf, J. M. (2005). Epidemiology of Clavibacter michiganensis subsp. sepedonicus in potato under European conditions: Population development and yield reduction. Journal of Plant Diseases and Protection, 112(1), 88-97.

Kaemmerer, D., Seigner, L., Poschenrieder, G., Zellner, M., \& Munzert, M. (2007). Epidemiology of bacterial ring rot of potato in plant and soil - Consequences for disease management. Journal of Plant Diseases and Protection, 114(4), 159-166.

Kakau, J., Abdel-Kader, D., Müller, P., Pastrik, K.-H., \& Seigner, L. (2004). Studies on the transmission of Clavibacter michiganenesis ssp.sepedonicus, the causal agent of bacterial ring rot, to the leaves of potato plants (English). Gesunde Pflanzen, 56, 111-115. https://doi.org/10.1007/s10343-0040039-6.

Kawchuk, L. M., Lynch, D. R., Kozub, G. C., Nelson, G. A., Kulcsar, F., \& Fujimoto, D. K. (1998). Multi-year evaluation of Clavibacter michiganensis subsp. sepedonicus disease symptoms in cultivated potato genotypes. American Potato Journal, 75, 235-243.

Kůdela, V. (2007). History of bacterial ring rot of potato in the Czech lands and a proposal for relaxation of strict quarantine measures. Plant Protection Science, 43(2), 35-46.

Li, X., Tambong, J., Yuan, K.(. X.)., Chen, W., Huimin, X., Lèvesque, C. A., \& De Boer, S. H. (2017). Reclassification of Clavibacter michiganensis subspecies on the basis of whole-genome and multi-locus sequence analyses. International Journal of Systematic and Evolutionary Microbiology, 68(1), 234-240. https://doi.org/10.1099 /ijsem.0.002492.

Logdson, C. E. (1967). Effect of soil temperature on potato ring rot. American Potato Journal, 44, 281-286.

Manzer, F. E., Gudmestad, N. C., \& Nelson, G. A. (1987). Factors affecting infection, disease development, and symptom expression of bacterial ring rot. American Potato Journal, 64, 671-676.

Marques, L. L. R., de Boer, S. H., Ceri, H., \& Olson, M. E. (2003). Evaluation of biofilms formed by Clavibacter michiganensis subsp. sepedonicus. (Abstr.). Phytopathology, 93, S57.

Nelson, G. A. (1980). Long-term survival of Corynebacterium sepedonicum on contaminated surfaces and in infected potato stems. American Potato Journal, 57, 595-600. https://doi. org/10.1007/BF02854129.

Nolte, P., Olsen, N., Bohl, W. H., \& Love, S. L. (2020). Seed and Planting Management. In J. C. Stark, M. Thornton, \& P. Nolte (Eds.), Potato Production Systems (pp. 136-154). Switzerland: Springer Nature Switzerland AG 2020.

Nouioui, I., Carro, L., García-López, M., Meier-Kolthoff, J. P., Woyke, T., Kyrpides, N. C., Pukall, R., Klenk, H. P., Goodfellow, M., \& Göker, M. (2018). Genome-based taxonomic classification of the phylum Actinobacteria. Frontiers in Microbiology, 9(2007). https://doi.org/10.3389 /fmicb.2018.02007.

Pánková, I., Krejzar, V., Ćepl, J., \& Kůdela, V. (2007). Detection of Clavibacter michiganensis subsp. sepedonicus in daughter tubers of volunteer potato plants. Plant Protection Science, 43(4), 127-134.

Pánková, I., Krejzar, V., \& Krejzarová, R. (2019). Categorisation of reactions and enumeration of bacteria in potato cultivars inoculated with the causal agent of bacterial ring rot. Plant Protection Science, 55, 11-22.

Paquin, R., \& Genereux, H. (1976). Effect du climat sur la flatrissure bacterienne de la pomme de terre et relation avec le contenu en sucres des tiges. Canadian Journal of Plant Science, 56, 549-554.

Pietraszko, M., Gryń, G., \& Przewodowski, W. (2018). An effect of weather and soil conditions and their interaction on infection of leaves and tubers of potato with bacteria Clavibacter michiganensis subsp. sepedonicus. American Journal of Potato Research, 95(3), 278-285. https://doi.org/10.1007 /s12230-017-9629-6.

Rykaczewska, K. (2015). The effect of high temperature occurring in subsequent stages of plant development on potato yield and tuber physio-logical defects. American Journal of Potato Research, 92, 339-349.

Skowera, B., \& Puła, J. (2004). Pluviometric extreme conditions in spring season in Poland in the years 1971-2000. Acta Agrophysica, 3(1), 171-177. 
Sletten, A. (1985). The effect of Corynebacterium sepedonicum on symptoms and field of four potato cultivars. Potato Research, 28, 27-33.

Stevens, L. H., Lamers, J. G., van der Zouwen, P. S., Mendes, O., van den Berg, W., Tjou-Tam-Sin, N. N. A., Jilesen, C. J. T. J., Spoorenberg, P. M., \& van der Wolf, J. M. (2017). Chemical eradication of the ring rot bacterium Clavibacter michiganensis subsp. sepedonicus on potato storage crates. Potato Research, 60, 145-158. https://doi.org/10.1007 /s11540-017-9342-3.

Van der Wolf, J. M., \& Van Beckhoven, J. R. C. M. (2004). Factors affecting survival of Clavibacter michiganensis subsp. sepedonicus in water. Journal of Phytopathology, 152, 161-168.

Van der Wolf, J. M., Elphistone, J. G., Stead, D. E., Metzler, M., Mülle, r P., Hukkanen, A., \& Karjalainen, R. (2005). Epidemiology of Clavibacter michiganensis subsp. sepedonicus, in relation control of bacterial ring. Report 95. Wageningen: Plant Research International.

Westra, A. A. G., \& Slack, S. A. (1994). Effect of interaction of inoculum dose, cultivar, and geographic location on the magnitude of bacterial ring rot symptoms expression in potato. Phytopathology, 84, 228-235.

Westra, A. A. G., Arneson, C. P., \& Slack, S. A. (1994). Effect of interaction of inoculum dose, cultivar, and geographic location on the development of foliar symptoms of bacterial ring rot of potato. Phytopathology, 84, 410-415.

Whitworth, J. L., Selstedt, R. A., Westra, A. A. G., Nolte, P., Duellman, K., Yellareddygari, S. K. R., \& Gudmestad, N. C. (2019). Symptom expression of mainstream and specialty potato cultivars to bacterial ring rot (Clavibacter sepedonicus) and evaluation of in-field detection. American Journal of Potato Research, 96(4), 427-444. 